\title{
Comparative study of different shading types on growth and yield of ginger plants
}

\author{
Mona M. Aly \\ Central Laboratory for Agricultural climate, Agriculture Research Center, Dokki, Egypt. \\ E-mail: mona_clac2003@yahoo.com
}

\author{
A.M. El Sawy \\ Central Laboratory for Agricultural climate, Agriculture Research Center, Dokki, Egypt.
} E-mail: alsawy1981@yahoo.com

Raghdaa A. El Gendy

Central Laboratory for Agricultural climate, Agriculture Research Center, Dokki, Egypt. E-mail: raghdaa09@yahoo.com

Received: 14 Oct. 2019 / Accepted 20 Nov. 2019/Publication date: 30 Nov. 2019

\begin{abstract}
Ginger plant recently is gaining attention in the food and pharmaceutical industries because of its medicinal importance and as a spice. This work aimed to evaluate the effect of different shading types on growth and yield of ginger plants (Zingiber officinale), during two seasons (2017 and 2018) at Dokki Research Station, Central Laboratory for Agricultural Climate, Egypt. The experiment consisted of seven treatments [Control (without shading), two levels of shade by using saran 30 and saran $60 \%$, the two level of shade covered with plastic $(30 \%+$ plastic cover and $60 \%+$ plastic cover) and intercropping ginger with sweet corn in different densities (4 ginger +4 sweet corn plants $/ \mathrm{m}^{2}$ and 4 ginger +8 sweet corn plants $\left./ \mathrm{m}^{2}\right)$ ]. The treatments were applied in a randomized complete block design with three replicates. Data for ginger growth parameters were obtained during the experiment period while the yield parameters were obtained at harvest. The results showed that the highest values of growth parameters were obtained from $60 \%$ shading+ plastic cover and intercropping ginger at 4 plants (with sweet corn) at 8 plants $/ \mathrm{m}^{2}$. Rhizome yield was increased with increasing levels of shade. The growth of ginger plants enhanced with decreasing light transmission and increasing relative humidity and air temperature. The economic evaluation shared that intercropping ginger at 4 with sweet corn at 8 plants $/ \mathrm{m}^{2}$ was more economic compared with net shade, net shade+ plastic and without shade.
\end{abstract}

Keywords: ginger, Zingber officinfle, sweet corn, shade, intercropping

\section{Introduction}

Ginger (Zingiber officinale) is a herbaceous perennial plant which belongs to Zingiberaceae family. This plant is native to tropical South East Asia, Africa and other tropical regions of the world (Adegbola and Olufunmilola, 2017). It is cultivated widely in the tropics for its showy flowers and useful products. The rhizome is valued for its flavour, contains two classes of constituents: the essential oils and oleoresins (Rhode et al., 2007). Ginger is one of the traditional medicinal plants that have been used by polynesians for treating many diseases such as; diabetes, high blood pressure, cancer and many other diseases (Ajav and Ogunlade, 2014). Essential oil and oleoresin are internationally commercialized for use in the food and pharmaceutical industries. Moreover, Ginger is also recommended by the traditional healers in South Asia, because it reduces the risk of cardiovascular diseases, high blood pressure and palpitations, and also serves as a vasodilator (Ghayur et al., 2005). In 2016, global production was 3.3 million tonnes, the greatest production belongs to India with 34\% of the world total (FAO, 2017). Ginger is a shade loving plant (Okwuowulu, 2005; Kratky et al., 2013). Previous studies showed that change in light intensity was able to modify the growth parameters and fresh yield of ginger (Ajithkumar and Jayachandran, 2003). According to Graham (1998), changes in light intensity with shade net were able to change synthesis of medicinal compounds in plants.

Corresponding Author: Mona M. Aly, Central Laboratory for Agricultural climate, Agriculture Research Center, Dokki, Egypt. E-mail: mona_clac2003@yahoo.com 
Intercropping being a unique practice of tropical and sub-tropical areas is becoming more popular among small scale farmers as it offers the yield advantage relative to sole cropping through yield stability and improved yield (Bhatti et al., 2006). Intercropping of corn in ginger crop is a common practice. However, the appropriate corn plant density to be applied on ginger crops is not known (Lyocks et al., 2013). The major intercrops used in large ginger growing countries are ginger with corn, corn with finger millet, corn with cassava, corn with buckwheat, and vegetables (Lachungpa, 2004). In Egypt, ginger is an unconventional crop. It is growing well in Mediterranean climate which provided the proper growing conditions. In this research, different types of shade were examined to get the best environmental condition for growing ginger widely in Egypt.

\section{Materials and Methods}

The experiment was carried out at Dokki Research station, Central Laboratory for Agricultural Climate, Egypt. In this investigation, there was a comparison between three types of shade. These types included cultivation ginger plants under tunnels covered with saran cloth only or with plastic cover either or intercropping ginger with tall plant (sweet corn).

Rhizome bits which used in cultivation were weighing $9+3 \mathrm{~g}$. In the third week of March 2017 and 2018, they were treated with a mixture of Mancozeb $(0.3 \%)$ and Ridomil Plus $(0.1 \%)$ for 30 minutes before cultivation. These rhizomes were germinated for 2 weeks in small pots, then they transplanted in tunnels and open field. Sweet corn seeds var. F1 Hytech 3010, were cultivated directly in the tunnels and open field on the second week of April. follows:

The plants were arranged in seven treatments which represented the three types of shading as

1- Control (T1): without any types of shade.

2- Intercropping ginger at 4 with sweet corn at $4 \mathrm{plant} / \mathrm{m}^{2}$ in the open field (T2): The ginger plants were cultivated in row and sweet corn in another row with the same number of plants in each row (4 plants).

3- Intercropping ginger at 4 with sweet corn at $8 \mathrm{plant} / \mathrm{m}^{2}$ in the open field (T3): The ginger plants were cultivated in row and sweet corn in two rows around the ginger row.

4- $60 \%$ shade (T4): Tunnel covered with black saran $60 \%$ shading. This tunnel dimension was $3 \mathrm{~m}$ length, $1 \mathrm{~m}$ width and $1 \mathrm{~m}$ high.

5- 30\% shade (T5): Tunnel covered with black saran 30\% shading. This tunnel dimension was $3 \mathrm{~m}$ length, $1 \mathrm{~m}$ width and $1 \mathrm{~m}$ high.

6- 60\% shade and plastic cover (T6): Tunnel covered with plastic cover then covered with black saran $60 \%$ shading. This tunnel dimension was $3 \mathrm{~m}$ length, $1 \mathrm{~m}$ width and $1 \mathrm{~m}$ high.

7- 30\% shade and plastic cover (T7): Tunnel covered with plastic cover then covered with black saran 30\% shading. This tunnel dimension was $3 \mathrm{~m}$ length, $1 \mathrm{~m}$ width and $1 \mathrm{~m}$ high.

Air temperature, relative humidity and solar radiation of each treatment were recorded by using agrometeorology Dokki station.

All these treatments were duplicated three times to represent three replicates. The experiment was arranged in a randomized complete block design (RCBD) with three replicates. Separation of means among treatments was determined using LSD test at 5\% (Steel and Torrie, 1980). Plants were harvested 16 weeks after exposure to different treatments. The data were collected for the two seasons (2017 and 2018). Growth parameters were recorded for the growing ginger crop under varying treatments. These parameters were: plant height, number of leaves per plant, leaf area per plant (it was measured by; C1-203 LASER AREA METER), dry matter and number of tillers per plant. The yield parameters recorded included number of rhizomes per plant, weight of rhizomes per plant, volatile oil content, starch and fiber content were estimated by AOAC method (1975).

\section{Results and Discussion}

Data of air temperature, relative humidity and solar radiation under seven treatments during seasons of 2017 and 2018 were presented in Figures (1, 2 and 3). 
There were no differences in air temperature among treatments in April. While, the differences were clearly observed in May, June and July. The greater value of air temperature was observed under $30 \%$ shade with plastic cover (T7) and 60\% shade with plastic cover (T6). The lowest value was detected under intercropping ginger at 4 with sweet corn at 8 plant $/ \mathrm{m}^{2}$ (T3) as shows in Figure (1). Relative humidity performance was changed. The highest value was illustrated when $60 \%$ shade with plastic cover (T6) was used while the lowest value was observed in control treatment (T1) as shown in Figure (2). Solar radiation trend changed as related to months. The highest value at all was found under control (T1) and the lowest value was found under 60\% shade with plastic cover treatment (T6) as shows in Figure (3).
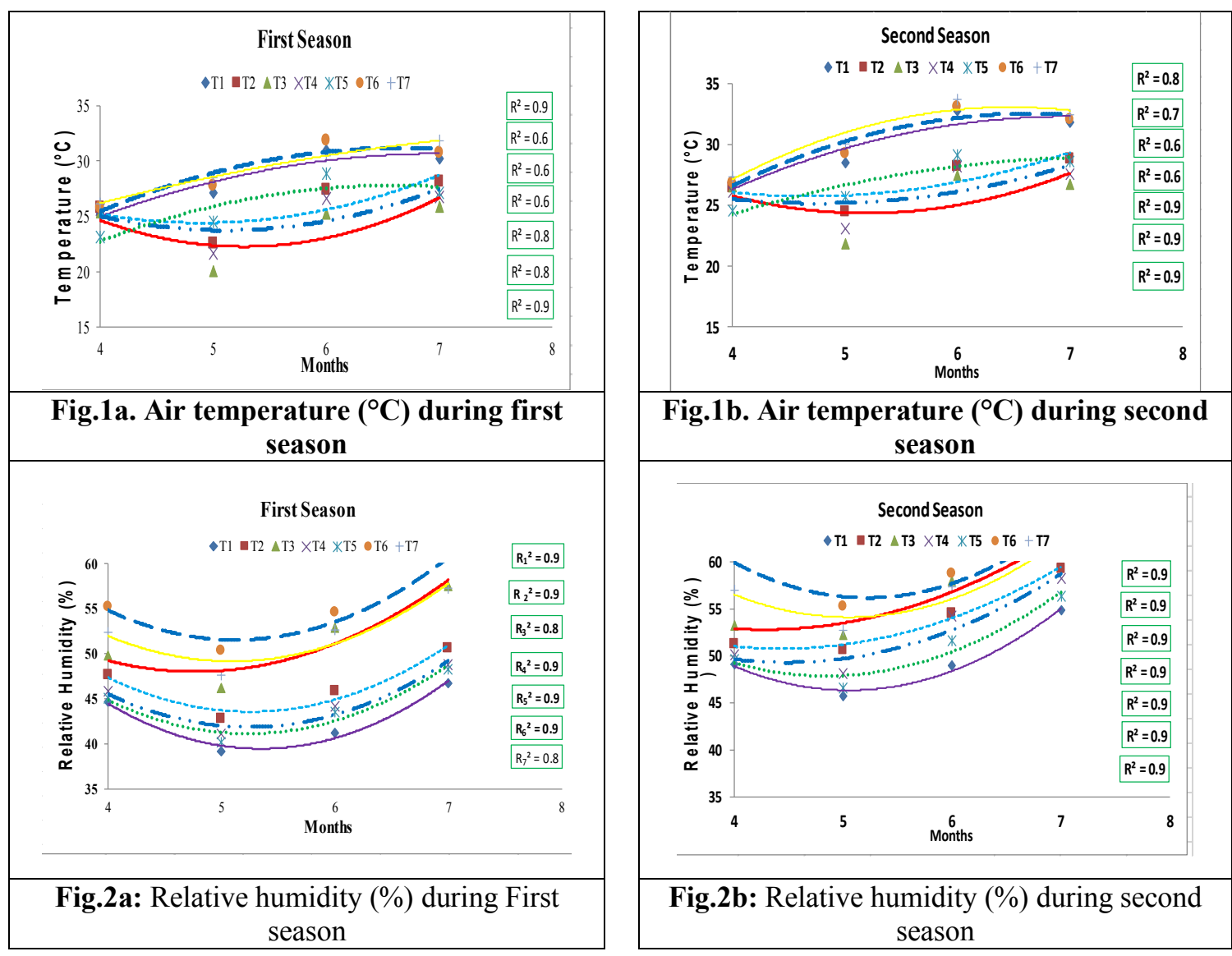

Fig.1b. Air temperature $\left({ }^{\circ} \mathrm{C}\right)$ during second

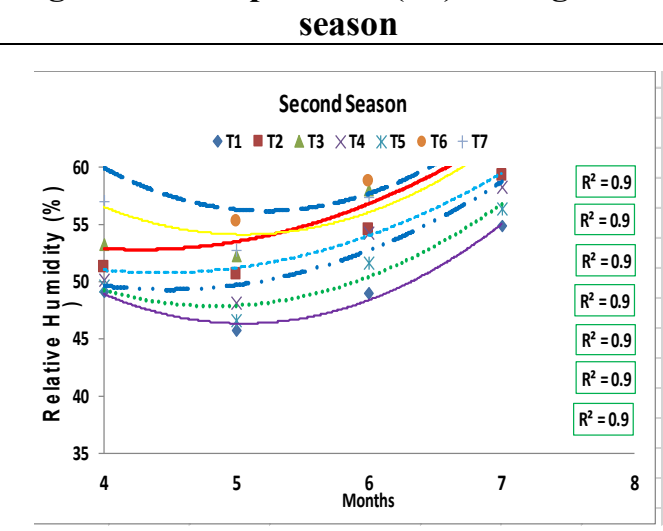

Fig.2b: Relative humidity (\%) during second season
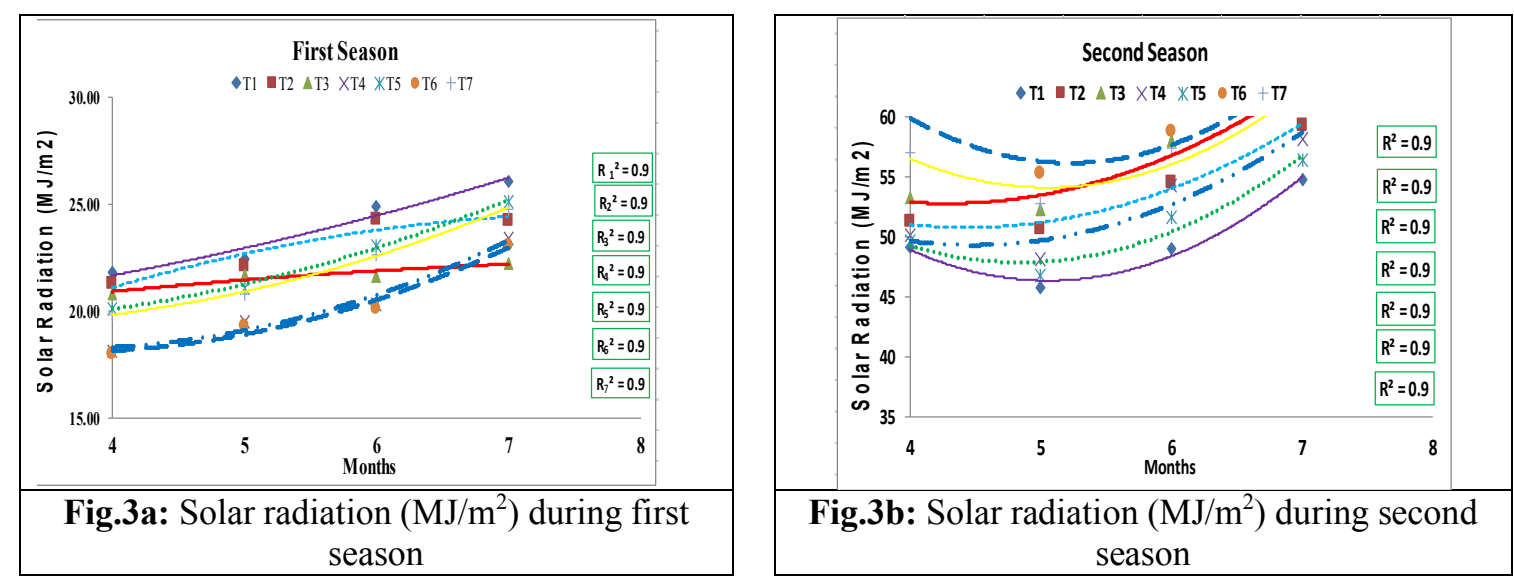

Fig.3b: Solar radiation $\left(\mathrm{MJ} / \mathrm{m}^{2}\right)$ during second season 
Data in Table (1) shows the effect of different shading types on vegetative parameter of ginger plants; plant height $(\mathrm{cm})$, number of leaves/plant, leaf area $\left(\mathrm{cm}^{2}\right)$ and dry matter $(\mathrm{g})$ during the two studied seasons. The highest values of plant height, number of leaves/plant, leaf area $\left(\mathrm{cm}^{2}\right)$ and dry matter were observed in $60 \%$ shade and plastic cover treatment (T6). However, the lowest value was found in control treatment (T1). The same trend was found in the second season.

Table 1: Effect of different shading types on vegetative parameter of ginger plants

\begin{tabular}{|c|c|c|c|c|c|c|}
\hline Treatments & Plant height (cm) & Number of leaves/plant & \multicolumn{2}{|c|}{ Leaf area $\left(\mathrm{cm}^{2}\right)$} & \multicolumn{2}{|c|}{ Dry matter (g) } \\
\hline \multicolumn{7}{|c|}{$\begin{array}{l}\text { First season } \\
\end{array}$} \\
\hline T1 & 38.52 & $21.86 \quad \mathrm{e}$ & 30.68 & $\mathrm{~g}$ & 1.07 & $\mathrm{e}$ \\
\hline $\mathbf{T 2}$ & 42.32 & 24.98 & 31.84 & $\mathrm{f}$ & 1.61 & d \\
\hline T3 & 43.72 & 30.51 & 36.56 & b & 2.48 & b \\
\hline T4 & 45.79 & 28.90 & 34.58 & $\mathrm{c}$ & 2.20 & $\mathrm{c}$ \\
\hline T5 & 43.56 & 27.69 & 32.61 & $\mathrm{e}$ & 2.02 & $\mathrm{c}$ \\
\hline T6 & 45.82 & 31.56 & 37.38 & $\mathrm{a}$ & 3.43 & $\mathrm{a}$ \\
\hline $\mathbf{T} 7$ & 44.32 & 28.82 & 33.78 & d & 1.72 & d \\
\hline \multicolumn{7}{|c|}{ Second season } \\
\hline T1 & 39.41 & $22.80 \quad$ e & 32.30 & $\mathrm{e}$ & 1.66 & d \\
\hline $\mathbf{T 2}$ & 43.24 & 25.82 & 33.51 & $\mathrm{e}$ & 2.50 & $\mathrm{c}$ \\
\hline T3 & 46.54 & 31.36 & 37.98 & $\mathrm{~b}$ & 3.19 & $\mathrm{~b}$ \\
\hline T4 & 44.19 & 29.82 & 35.71 & $\mathrm{c}$ & 2.71 & bc \\
\hline T5 & 44.17 & 28.56 & 35.29 & $\mathrm{~d}$ & 2.59 & $\mathrm{c}$ \\
\hline T6 & 46.84 & 32.50 & 40.46 & $\mathrm{a}$ & 3.79 & $\mathrm{a}$ \\
\hline T7 & 44.93 & 29.87 & 35.29 & $\mathrm{~d}$ & 2.31 & c \\
\hline
\end{tabular}

Control (T1), Intercropping ginger at 4 with sweet corn at 4 plant $/ \mathrm{m}^{2}$ in the open field (T2), Intercropping ginger at 4 with sweet corn at 8 plant $/ \mathrm{m}^{2}$ in the open field (T3), 60\% shade (T4), 30\% shade (T5), 60\% shade with plastic cover (T6), 30\% shade with plastic cover (T7).

The effect of different shading type on rhizome parameters is presented in Table (2). Shading type had a significant effect on number of tillers per plant, number of rhizomes per plant and weight of rhizomes per plant. The highest values of these parameters were obtained under $60 \%$ shade and plastic cover treatment (T6). On the other hand, ginger plants which grown in the open field without any shade (control T1) showed a reduction in rhizome parameter compared to the other treatments.

Control (T1), Intercropping ginger at 4 with sweet corn at 4 plant $/ \mathrm{m}^{2}$ in the open field (T2), Intercropping ginger at 4 with sweet corn at $8 \mathrm{plant} / \mathrm{m}^{2}$ in the open field (T3), $60 \%$ shade (T4), $30 \%$ shade (T5), $60 \%$ shade with plastic cover (T6), 30\% shade with plastic cover (T7).

Table 2: Effect of different shading types on rhizome parameters of ginger plants

\begin{tabular}{ccccccc}
\hline Treatments & $\begin{array}{c}\text { Number of tillers } \\
\text { /plant }\end{array}$ & \multicolumn{4}{c}{$\begin{array}{c}\text { Number of } \\
\text { rhizomes/plant }\end{array}$} & $\begin{array}{c}\text { Weight of rhizomes/plant } \\
\text { (g) }\end{array}$ \\
& & First season & f & 147.89 & $\mathrm{~d}$ \\
T1 & 3.34 & $\mathrm{f}$ & 3.74 & $\mathrm{e}$ & 278.00 & $\mathrm{c}$ \\
T2 & 3.80 & $\mathrm{e}$ & 4.28 & $\mathrm{a}$ & 458.11 & $\mathrm{a}$ \\
T3 & 6.55 & $\mathrm{~b}$ & 6.51 & $\mathrm{bc}$ & 366.11 & $\mathrm{~b}$ \\
T4 & 5.45 & $\mathrm{c}$ & 5.54 & $\mathrm{~d}$ & 255.00 & $\mathrm{c}$ \\
T5 & 4.12 & $\mathrm{e}$ & 5.02 & $\mathrm{de}$ & 519.33 & $\mathrm{a}$ \\
T6 & 7.41 & $\mathrm{a}$ & 6.45 & $\mathrm{ab}$ & 371.11 & $\mathrm{~b}$ \\
T7 & 4.64 & $\mathrm{~d}$ & 5.09 & $\mathrm{~cd}$ & & \\
T1 & & & Second season & & & $\mathrm{d}$ \\
T2 & 4.34 & $\mathrm{f}$ & 4.57 & $\mathrm{e}$ & 252.89 & $\mathrm{~cd}$ \\
T3 & 4.58 & $\mathrm{ef}$ & 5.30 & $\mathrm{~d}$ & 350.11 & $\mathrm{ab}$ \\
T4 & 7.16 & $\mathrm{~b}$ & 7.29 & $\mathrm{a}$ & 523.02 & $\mathrm{ab}$ \\
T5 & 6.24 & $\mathrm{c}$ & 6.47 & $\mathrm{~b}$ & 463.67 & $\mathrm{~cd}$ \\
T6 & 4.94 & $\mathrm{de}$ & 5.98 & $\mathrm{bc}$ & 336.11 & $\mathrm{a}$ \\
T7 & 8.16 & $\mathrm{a}$ & 7.71 & $\mathrm{a}$ & 559.86 & $\mathrm{bc}$ \\
\hline
\end{tabular}

Control (T1), Intercropping ginger at 4 with sweet corn at 4 plant $/ \mathrm{m}^{2}$ in the open field (T2), Intercropping ginger at 4 with sweet corn at 8 plant $/ \mathrm{m}^{2}$ in the open field (T3), 60\% shade (T4), 30\% shade (T5), 60\% shade with plastic cover (T6), 30\% shade with plastic cover (T7). 
The results of rhizomes chemical contents (volatile oil, fiber and starch) measured after 120 days after planting during the two studied seasons are tabulated in Table (3). Significant differences between different shading types were submitted. The highest value of volatile oil was obtained in T6, while the lowest value was observed in control treatment. On the other hand, the highest fiber and starch content were found in the control treatment, and the lowest values were found in T6.

Table 3: Effect of different shading type on rhizomes chemical contents of ginger plants

\begin{tabular}{|c|c|c|c|c|c|c|}
\hline Treatments & \multicolumn{2}{|c|}{ Volatile oil } & \multicolumn{2}{|c|}{ Fiber } & \multicolumn{2}{|c|}{ Starch } \\
\hline \multicolumn{7}{|c|}{ First season } \\
\hline T1 & 1.91 & $\mathrm{f}$ & 7.28 & $\mathrm{a}$ & 45.44 & $\mathrm{a}$ \\
\hline $\mathbf{T} 2$ & 2.85 & $\mathrm{~cd}$ & 6.65 & $\mathrm{~b}$ & 41.91 & $\mathrm{~b}$ \\
\hline T3 & 3.40 & bc & 3.46 & $\mathrm{f}$ & 33.45 & $\mathrm{f}$ \\
\hline T4 & 3.90 & $a b$ & 4.36 & e & 35.12 & $\mathrm{e}$ \\
\hline T5 & 2.19 & $\mathrm{e}$ & 5.52 & $\mathrm{c}$ & 40.70 & $\mathrm{c}$ \\
\hline T6 & 4.22 & $\mathrm{a}$ & 3.26 & $\mathrm{f}$ & 31.24 & $\mathrm{~g}$ \\
\hline T7 & 2.77 & de & 4.73 & d & 39.05 & d \\
\hline \multicolumn{7}{|c|}{ Second season } \\
\hline T1 & 2.57 & d & 7.82 & $\mathrm{a}$ & 46.48 & $\mathrm{a}$ \\
\hline $\mathbf{T} 2$ & 3.42 & $\mathrm{c}$ & 5.28 & $b$ & 42.72 & $\mathrm{~b}$ \\
\hline T3 & 4.74 & $a b$ & 3.32 & $\mathrm{f}$ & 34.54 & $f$ \\
\hline T4 & 4.52 & $\mathrm{~b}$ & 3.92 & $\mathrm{e}$ & 36.06 & $\mathrm{e}$ \\
\hline T5 & 3.18 & $\mathrm{c}$ & 4.89 & $\mathrm{c}$ & 41.60 & $\mathrm{c}$ \\
\hline T6 & 5.11 & $\mathrm{a}$ & 2.69 & $\mathrm{~g}$ & 32.10 & $\mathrm{~g}$ \\
\hline T7 & 3.50 & $\mathrm{c}$ & 4.35 & $\mathrm{~d}$ & 39.42 & $\mathrm{~d}$ \\
\hline
\end{tabular}

Ginger plants growth enhanced with decreasing in light transmission with increasing in relative humidity with increasing in warm air. There is a relationship between relative humidity and temperatures; warm air can hold more water vapor than cool air. Relative humidity decreases when the temperature increases if no moisture is added to the air. (Hemm et al., 2004; Briskin and Gawienowski, 2001; Kurata et al., 1997). Changes in light intensity with shade net were able to change synthesis compounds in plants (Graham, 1998). Whether similar environmental conditions when exerted upon ginger were able to modify the production and profiling of its bioactive compounds in different plant parts, or totally alter the plant bioactive constituents, or could there be a species-related response to the impact of environmental factors.

\section{The Economic Evaluation}

Data in Table (4) and Fig (4) displayed the economic evaluation of the different shading types on ginger plants. Obviously, data stated that the treatment of intercropping ginger at 4 with sweet corn at $8 \mathrm{plant} / \mathrm{m}^{2}$ in open field achieved the highest net income. This result was concerning the economic treatment to the farmer than the other treatment.

Table 4: Economic evaluation of the different shading types on ginger plants

\begin{tabular}{|c|c|c|c|c|c|c|c|c|}
\hline \multirow[t]{2}{*}{ Treatments } & \multicolumn{2}{|c|}{ Yield (g) } & \multicolumn{2}{|c|}{ Yield Price (EGP) } & \multicolumn{2}{|c|}{$\begin{array}{c}\text { Total Cost } \\
\text { (EGP) }\end{array}$} & \multicolumn{2}{|c|}{ Net Income (EGP) } \\
\hline & 2017 & 2018 & 2017 & 2018 & 2017 & 2018 & 2017 & 2018 \\
\hline T1 & 591.56 & 1011.56 & 31.94 & 47.54 & 5.77 & 5.54 & 26.17 & 42.00 \\
\hline $\mathbf{T 2}$ & 1120.00 & 1408.44 & 100.05 & 109.82 & 17.97 & 17.71 & 82.08 & 92.11 \\
\hline T3 & 1848.44 & 2108.08 & 178.95 & 186.33 & 29.00 & 28.86 & 149.96 & 157.46 \\
\hline T4 & 1464.44 & 1854.68 & 79.08 & 87.17 & 23.41 & 22.72 & 55.67 & 64.45 \\
\hline T5 & 1020.00 & 1344.44 & 55.08 & 63.19 & 21.57 & 20.88 & 33.51 & 42.30 \\
\hline T6 & 2077.32 & 2239.44 & 112.18 & 105.25 & 40.38 & 39.67 & 71.80 & 65.58 \\
\hline T7 & 1484.44 & 1709.84 & 80.16 & 80.36 & 38.59 & 37.87 & 41.57 & 42.49 \\
\hline
\end{tabular}




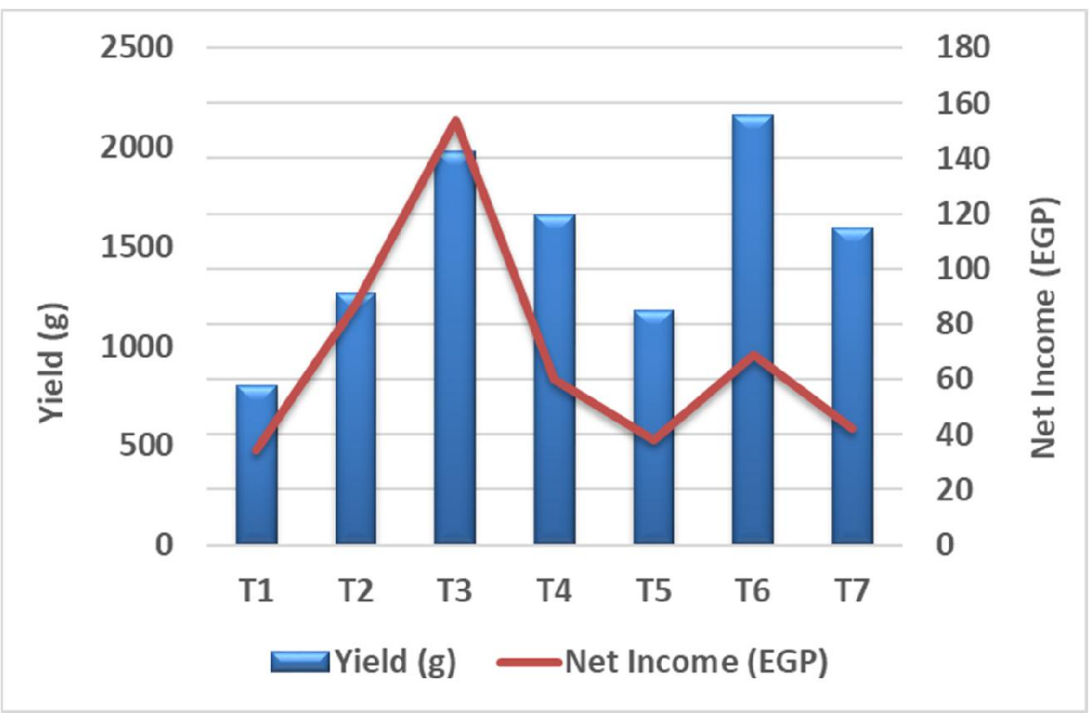

Fig 4: Economic of the different shading types on ginger plants

\section{References}

Adegbola, O. D., and A. A. Olufunmilola, 2017. Comparative study of the effect of dry and wet ginger (Zingiber officinale Roscoe) spice on the proximate and microbial safety of soybean beverage. Croat. J. Food Sci. Technol. 9 (2): 130 - 135

Ajav, E.A. and C.A. Ogunlade, 2014. Physical Properties of Ginger (Zingiber Officinale). Global Journal of Science Frontier Research: D Agriculture and Veterinary 14 (8).

Ajithkumar, K. and B.K. Jayachandran, 2003. Influence of shade regimes on yield and quality of ginger (Zingiber officinale Roscoe) Journal of Spices and Aromatic Crops 12 (1): 29-33.

AOAC. 1975. Official Methods of Analysis. Association of Official Agricultural Chemists, Washington D.C. 121h Edn

Bhatti, I.H., R. Ahmad, A. Jabbar, M.S. Nazir, and T. Mahmood, 2006. Competitive behavior of component crops in different sesame legume intercropping systems. Int. J. Agric. Biol. 8:165167.

Briskin, D.P. and M.C. Gawienowski, 2001. Differential effects of light and nitrogen on production of hypericins and leaf glands in Hypericum perforatum. Plant Physiol. 39: 1075-1081.

Food and Agriculture Organization of the United Nations, Statistics Division, 2017. "Ginger production in 2016, Crops/ Regions/ World/ Production/ Quantity (from pick lists)".

Ghayur, M.N., A.H. Gilani, M. B. Afridi, and P.J. Houghton, 2005. Cardiovascular effects of the ginger aqueous extract and its phenolic constituents are mediated through multiple pathways. Vascular Pharmacology 43 (4): 234-241. https://doi.org/10.1016/j.vph.2005.07.003

Graham, T.L. 1998. Flavonoid and flavonol glycoside metabolism in Arabidopsis. Plant Physiol. Biochem., 36: 135-144.

Hemm, M.R., S.D. Rider, J. Ogas, D.J. Murry, and C. Chapple, 2004. Light induces phenylpropanoid metabolism in Arabidopsis roots. Plant J., 38: 765-778

Kratky, B.A., C. Bernabe, E. Arakaki, F. White, and S. Miyasaka, 2013. Shading Reduces Yields of Edible Ginger Rhizomes Grown in Sub-Irrigated Pots. Root Crops May 2013 RC-2

Kurata, H., S. Matsumura, and S. Furusaki, 1997. Light irradiation causes physiological and metabolic changes for purine alkaloid production by a Coffea arabica cell suspension culture. Plant Sci. 123: 197-203.

Lachungpa, K., 2004. Intercropping of agri/horti crops with special reference to mandarin (Citrus reticulata Blanco) in Sikkim (INDIA). Australian Agronomy Conference.

Lyocks, S.W.J., J. Tanimu, and L.Z. Dauji, 2013. Growth and yield parameters of ginger as influenced by varying populations of maize intercrop. Journal of Agricultural and Crop Research 1 (2): 24-29. 
Okwuowulu, P.A., 2005. Ginger in Africa and the Pacific Ocean Islands. In P. N. Ravindran \& K. Nirmal Babu (Eds.). Ginger London: Taylor and Francis. 31:279-303

Rhode, J., S. Fogoros, S. Zick, H. Wahl, K. A. Griffith, J. Huang, and J. R. Liu, 2007. Ginger inhibits cell growth and modulates angiogenic factors in ovarian cancer cells. BMC complementary and Alternative med. 7, 44. https://doi.org/10.1186/1472-6882-7-44

Steel, R.G.D. and J.H. Torrie, 1980. Principles and Procedures of Statistics. A Biometrical Approach. ( $2^{\text {nd }}$ Edition). Mc. Graw Hill. N. Y. 